\title{
Social Distancing, Cultural and Psychological Effects on Learners in a Rural Setting in Zimbabwe
}

\author{
Ncube Sikhangezile and Motalenyane Alfred Modise ${ }^{1}$ \\ Central University of Technology, Free State, South Africa
}

\begin{abstract}
Social distancing has proven to be one effective reaction to the threat of increasing numbers of Coronavirus (COVID-19) cases and fatalities. The crisis around COVID-19 and social distancing is leaving an indelible footprint on the hearts and minds of the learners. The impact and ripple effects around the teaching and learning fraternities is likely too vast to comprehend for the learners. The study seeks to unveil the socio-cultural and psychological effects of social distancing on the learners in Zimbabwe. The study was limited to Matabeleland North Province of Zimbabwe. Respondents were 10 learners from secondary schools and 10 from primary schools. Data were electronically collected to observe the ongoing lockdown and social distancing measures. Semi-structured interview schedules were the tools for data gathering. The study was underpinned using the interactionist, socio-cultural theory of Vygotsky and Sullivan's interpersonal theory. The findings of the study revealed that learners lack psychosocial support from home. The situation is causing stress, depression, loss of feeling of control over one's life, low self-esteem and loss of aspiration. There is also unavailability of peer support, peer tutoring, co-operative and competitive learning and resources which are essential pedagogies for effective learning. Access to the Internet is a challenge for many learners due to the poor economic status of the country. Most of the learners are worried about their well-being and that of their family-members in-turn, this affects the academe. Guidance and counselling lessons have become more vital to support learners during this social distancing era.
\end{abstract}

Keywords: coronavirus, covid-19, learners, lockdown, social distancing, Zimbabwe.

The Corona Virus (Covid-19) pandemic, which first began in China, has been sweeping across the world at a furious pace. It has infected and affected a massive population worldwide, and Zimbabwe has not been spared from this devastating disease (Garbe et al., 2020; Tarman, 2020). COVID-19 has brought the world to a standstill as most countries have undergone lockdowns instilling fear and instability and provoking different cultural and psychological states from students. In treating the COVID-19 pandemic, the world is fighting to erect enough facilities to treat those infected with the deadly, highly contagious virus (Aliyyah et al., 2020; Kelley, 2020; Ojha, 2020). However, most countries, Zimbabwe included are not setting up the necessary facilities for psychological help for the affected, and many of the learners in Zimbabwe fall in this category. Any public health emergency will have negative psycho-social effects. As we try to prevent infection and save lives, masses, learners are getting forced into social distancing that breaks the necessary social connectedness that they need.

\footnotetext{
${ }^{1}$ Corresponding Author E-mail: mamodise@cut.ac.za
} 
The World Health Organisation (WHO, 2020) indicated that on December 31 of 2019, the World Health Organization China Country Office learned of cases of pneumonia of unknown aetiology (unknown cause) detected in Wuhan City, Hubei Province of China. From December 31, 2019, through January 3, 2020, a total of 44 case-patients with pneumonia of unknown aetiology were reported to the World Health Organization by the national authorities in China. South Africa has the highest number of cases followed by Egypt $(11,228)$, Algeria (6 630), Ghana (5,638), and Nigeria $(5,450)$; however, Egypt had the highest number of deaths at 592. Within the SADC region, South Africa has had 79\% of the total cases and $69 \%$ of the total deaths. As have other nations, Zimbabwe has had to take social isolation measures that have impacted children and schooling. Such impacts have been severe and adverse to most learners in Zimbabwe.

As Cancer Care (2020), has highlighted, humans are inherently social creatures, and being cut off from others for long periods can increase feelings of loneliness, depression, low self-esteem and a lack of sense of belonging. Hau Yan Ho (2020) noted that human beings create and define our sense of identity, purpose and meaning mainly within our relationships and connections in communities. A progressive disintegration of these networks threatens the sense of normalcy, safety, belonging and personhood (Molefe, 2018). According to Serafini, Parmigiani, Amerio, Aguglia, Sher, Land, and Amore (2020), this disintegration can result in damaging mental and emotional outcomes such as fear, anxiety, depression, and loneliness. Thus, the confinement experienced by learners in Africa and internationally because of lockdowns and social distancing can trigger feelings of helplessness, entrapment and frustration in these youngsters (López \& Rodó (2020)

Bjorklund and Salvanes (2011), said that going to school is the best public policy tool available to raise skills. While school time can be fun and can develop social skills and social awareness, from an economic point of view, the primary point of being in school is that it increases a child's ability. Even a relatively short time in school does this; even a relatively short period of missed school will have consequences for skill growth. Thus, the transition to home learning as a way to practice social distancing is a disruption for virtually every child in Zimbabwe. However, the extent of its harmfulness will depend on how home learning is implemented in each school and each family and also on an individual learner's psycho-social state. According to Hau Yan Ho (2020), children need to play. They need to go to school not only to learn but to interact with others, as part of child development. The national lockdown in Zimbabwe has temporarily put all that on hold, and this may impact very negatively on a children's psycho-social well-being. Hau Yan Ho (2020) added that change in the comfortable routines in which children thrive could affect their confidence and trigger anger, frustration and anxiety.

Learmonth (2018) reveals that as young children are learning the basics of being social beings, their parents and siblings provide most of the input they need, while older children and adolescents are learning to navigate complex social groups of peers. Ho, Chui and Borschel (2017), concurred that social development can take place mostly within the family, but that as children get older and more socially adept, their peer group becomes the more critical hub of social development. Thus, the lockdown and social distancing measures could have a significant and adverse psycho-social impact on youths above all population cohorts. This points to the present condition of most secondary school learners in Zimbabwe. Psychologist Erikson's seminal work on psycho-social development notes that youth are at the stage of establishing essential bonding and intimacy with loved ones, peers and society in general (Hau Yan Ho, 2020)

Those who complete this stage of development go on to create and maintain healthy and functional relationships with people, as well as become responsible citizens within their communities. Youth unable to do so, often struggle with recurrent feelings of loneliness and isolating behaviours, potentially leading toward a life of stagnation and disconnection from 
society. According to Makola and Modise (2018), moral support, care and love are essential to health issues, and challenging times, as young people, learners or kids require support from family, teachers, and peers, because these groups are close to young, learners or children and are open with one another. Parents, teachers, peers and community are needed during this challenging time to support the learners, or young people

Peer tutoring is a system of using learners to tutor other students. These programs can operate during regular class time as group activities or outside of class. Peer tutoring offers significantly more potential advantages than disadvantages. The old saying goes like this, "to teach is to learn twice." This old saying suggests that teachers learn by teaching. A study that Topping (2005) conducted for the psychology department at The University of Dundee suggests that the adage is true; peer tutors enhance their understanding of the material by teaching it to other students.

Boz Yaman (2019) highlighted that learners who receive peer tutoring feel more comfortable receiving instruction from fellow learners than adult teachers, according to the. Feeling at ease with a peer tutor allows a student to concentrate better on the tasks of the lesson, which can then transfer into higher achievement. Peer tutoring also helps develop personal relationships between the tutor and the student. Each student improves his or her social skill set because unlike traditional instruction, peer tutoring occurs either in one-on-one meetings or in small groups, which requires more focused communication between tutors and learners (Cascio, 2014). Thus, the pertinent question is: Are peer tutoring and its massive advantages to learners possible under the lockdown and social distancing regulations in Zimbabwe?

The thrust of this study is to explore and discuss the cultural and psychological effects of lockdown and social distancing on learners in Zimbabwe; The study further seeks to inform on the behaviour and lifestyle of learners during the COVID 19 lockdown in Zimbabwe; and also challenge the schools and school authorities on lockdown policies and practices that affect learners.

\section{Theoretical Framework}

The study was underpinned on the interactionist, socio-cultural theory of Vygotsky and Sullivan's interpersonal theory. Vygotsky's theories stress the fundamental role of social interaction in the development of cognition, as he believed strongly that the community plays a central role in the process of "making meaning." Vygotsky places considerably more emphasis on social factors contributing to cognitive development (Aydin, 2019; McLeod 2014, Williams 2020). Vygotsky states that cognitive development stems from social interactions from guided learning within the zone of proximal development as children and their partners co-construct knowledge (John-Steiner and Mahn (1996), Visser (2015), Shabani (2016). Sullivan (1953), who posited the interpersonal theory, believed that all psychological disorders have an interpersonal origin and can be understood only with reference to the patient's social environment. Sullivan focused on anxiety as being a consequence of faulty social interactions. The theorist believes that people develop a personification of self and others through the integration (Tasman et al., 2008). These theories underline that interpersonal factors influence human beings' mental state and cognitive development. Thus, these theories are clamouring for a rich socio-cultural environment, for children to intellectual grow and obviate psychological disorders (Boutelier, 2019; Galkiene \& Puskoriene, 2020; Monkeviciene et al., 2020).

\section{Methodology}

The qualitative approach and the phenomenology design were employed to collect data for the study. Polit and Beck (2014) defined a qualitative research approach as an investigation 
of phenomena typically in an in-depth and holistic manner, through the collection of rich narrative materials using flexible data collection methods. Phenomenology attempts to unearth possible insights regarding the world as it is immediately experienced. Phenomenological research design is regarded as the most suitable design to collect data to gain clear, first-hand information with no assumptions (Neubauer, Witkop, \& Varpio 2019). The qualitative approach was selected to elicit data for the study because of its principles and interest in studying life as it is lived in real situations. The approach was considered the best for managing topics, like this one, where the behaviour and lifestyle of learners are assessed.

\section{Participants and Setting}

The participants were learners who were drawn from a convenience sample; 10 learners from secondary schools and 10 from primary schools were selected to make a total representative sample of 20. Participants were from Umguza, Binga and Hwange districts of Matabeleland North Province of Zimbabwe. The WhatsApp study groups formed in these districts to learn during social distancing and lockdown were used to sample participants. The participants were mainly Black, Ndebele speakers and the sample represented rural settings of both secondary and primary levels. Most participants (90\%) self-identified as followers of the Christian faith.

\section{Data Collection And Procedure}

Data were electronically collected to observe the ongoing lockdown and social distancing measures, to avoid the spread of Coronavirus and obey the lockdown regulation by the government of Zimbabwe. Semi-structured interview schedules were the tools for data gathering. Participants were recruited via social media because it was an appropriate platform to contact the participants. The participants volunteered for the study. The purpose of the research was explained to the participants. The names of the respondents were not identified for ethical reasons. The participants provided informed consent to the study. The purpose of the research was explained to the participants. The participant learners completed a semi-structured individual interview on their personal beliefs and learners experience during the Coronavirus period Matabeleland North Province of Zimbabwe. The researcher conducted the interviews in Ndebele and English at home. The learners completed the interviews at a convenient time for them and the lead researcher. Interviews were concurrently transcribed and then translated for analysis.

\section{Data Analysis}

Data were thematically analysed using open-coding procedures (King \& Horrocks, 2010). These procedures involved systematically organising, categorising, and summarising data; followed by describing it in meaningful themes. Themes were assigned codes to condense the data into categories. For the data reporting, randomly assigned numbers were used to assure confidentiality.

\section{Findings And Discussion}

The thematic analysis resulted in the four themes (1) psycho-social support from home, (2) stress during COVID-19 at home, (3) filling basic needs and resources for learning, and (4) peer support. Each of these themes and the evidence for them is presented below. 


\section{Theme 1: Psycho-Social Support From Home}

As the Coronavirus continues to spread, and the schools are continuously closed to observe and practice social distancing, many learners in Zimbabwe are experiencing the realities of social isolation in an unprecedented way. There is uncertainty around the learners as to when they will be allowed to return to school and what school will be like when they do. This anxiousness comes with a lot of stress and anger and behavioural disorders as revealed by the participants.

Several respondents discussed this. For example, Respondent 3 said,

I respect the rules and regulations of the Covid-19 lockdown to protect myself and to protect the next person. Basically, what has affected another human being has also affected me despite language, colour, continent or country. It's really important for people to take heed because people are dying, but I'm anxious about going back to school.

Respondent 7 added,

We are learning online as learners, but it is very difficult to learn since we have lots of problems, and therefore it is difficult to concentrate at home.

Lastly, respondent 5 noted,

How do you learn at home with an empty stomach, with stress, anxiety and depression at the same time with parents who are not working, and no income at home.

The study found that given the new rules on lockdown and social distancing, various methods of remote teaching had replaced traditional learning. However, remote teaching creates teething problems in terms of getting used to technology, loss of face-to-face contact and in specific disciplines, ability to access essential facilities such as laboratories. Educational authorities across the nation require educators to provide lessons and digital resources, despite their varying levels of knowledge about and support for which instructional technologies are most effective for whom, how and under what conditions. Mohamedbhai (2020) said that it was a fallacy to believe that online learning could be effective by merely posting a teachers' notes online or having a video recording of the lecture.

\section{Theme 2: Stress During COVID-19 At Home}

About $98 \%$ of learners reported said that they had experienced stress, and this stress affected their academic activities. For example,

Respondent 6 noted that

Social distancing is the core concept here, and the challenge is how to sustain us (students) engaged. We spend too much time at home lonely with nothing to do, and this is stressful and killing the vibe. 
Respondent 3 said,

This is a very lonely disease. It is very painful no matter what cultural context one comes from. Social isolation and lack of social and physical contact cause feelings of loneliness.

These views were in line with the observation by Campbell (2020) that, this situation can cause stress, depression, loss of feeling of control over one's life, low self-esteem and a loss of aspiration.

The study indicated that learners in Matabeleland North province of Zimbabwe experienced stress due to the environment and lack of support from the state and parents due to economic status in Zimbabwe and this has negatively impacted their studies during the COVID19 lockdown. According to, Kumar (2020), people who are quarantined are very likely to develop a wide range of symptoms of psychological stress and disorder, including low mood, insomnia, stress, anxiety, anger, irritability, emotional exhaustion, depression and posttraumatic stress symptoms. In line with that, Responded 8,revealed,

We normally take these bodily gestures like the smile, hugs and pats for granted, but when they are not there, the psycho-social environment is affected and for us, learners it will eventually affect the academics.

These views align with the observations of Cancer Care (2020) that stress in moderate doses is healthy. Stress is our body's way of responding to events that threaten or challenge us. However, chronic stress impairs our ability to function well and impacts the quality of our relationships.

\section{Theme 3: Basic Needs and Resources for Learning}

The study reported that $95 \%$ of learners are suffering during COVID 19 due to lack of support and getting basic need at home. For example, Respondent 8, said that

The lockdown is a necessary measure, but it leaves the vulnerable faced with hunger, and an intense lack of basics, let alone studying online.

Media feeds are being inundated with anecdotes of our nation's parents jumping on the homeschooling and digital learning bandwagons. They are at the mercy of the information available to them and the technological tools to which their children and households may have access. Some areas do not receive any form of network signals, but some learners are supposed to be learning online. The country is going through a rough economic phase where some families cannot even put food on the table, let alone data and gadgets to enable e-learning for their children. Respondent 9 added,

My parents are not working like other parents, and therefore my parents cannot afford to buy basic needs like other parents who are working and secondly it is challenging to do my studies because I do not have a computer, even data to send emails or to research. 
The study revealed that children from better-off families are accessing home learning better than those from poorer families. Learners from disadvantaged backgrounds, who already achieve less in academics, have their situations further exacerbated by this social distancing and e-learning. All these were the effects of social distancing highlighted by the learners in Zimbabwe. Thus, the conclusion can be reached that the playing field in education has never been equal for all learners, and these differences have further widened in this the new normal.

However, this is what is happening in Zimbabwe, and learners who are at the receiving end of the product suffer as the anomalies impact heavily on both the socio-psychological and the cognitive domains.

Mohamedbhai (2020) said that quality online learning requires that a professional instructional designer prepares the teaching material, also that the teachers are pedagogically trained for delivering the programme, and the learners are equally exposed to the pedagogy of online learning. Learners are suffering because of their economic status at home and cannot afford the basic needs and technology to learn. All these factors mean that preparedness lags in the presentation of lessons in Zimbabwean schools hence the teething problems of the programme.

\section{Theme 4: Peer Support}

About $98 \%$ of the learners reported being not supported at home during COVID-19. For example, Respondent one said,

Studying alone from home is like running a race alone. We always need to pull and push each other in different concepts.

Responded 2,lamended

I need competition to work extra harder, but in this confinement, I feel discouraged and lose the zeal to study.

Learners claimed that studying in confinement was difficult, and they needed each other. Most learners claimed that in some respects, they learned them better by observing their peers. Most respondents were against the social distancing, and they preferred to mingle and mix as they studied. They felt that their studies thrived better in a lively atmosphere with their peers from different backgrounds, experiences and intellectual levels than in their personal spaces. In his study, Modise (2018) indicated that peers have a vital role to play in promoting a healthy lifestyle and well-being of learners or students and peers may be more accessible than the family because peers are free to talk to each other

\section{Conclusion and Recommendations}

The study sought to reveal the socio-cultural and psychological effects of social distancing on learners in Matabeleland North Province of Zimbabwe. The study found that learners lack psycho-social support, a situation that is causing stress, depression, loss of feeling of control over one's life, lowered self-esteem and a loss of aspiration.

The study further indicated that a lack of peer support, peer tutoring, co-operative and competitive learning and resources for teaching and learning and access to technology hinders the academic progress. The research study found that teachers are pedagogically trained for delivering the programme, but learners suffer because of their economic status at home and cannot afford the basic needs and technology to learn. All these factors mean that preparedness 
lags in the presentation of lessons and the learning process has been adversely impacted in Matabeleland North Province Zimbabwean schools.

The findings attest to the need to focus on the strategies or intervention programmes to support well-being among learners whom COVID-19 affects in Matabeleland North Province of Zimbabwe. Makola and Modise (2018) asserted that people who are vulnerable need support, love, care, acceptance and proper guidance from the Church during a time of trial and confusion in life and, without the support, of different stakeholders this increases their stress and they become hopeless. Moreover, Modise (2017) asserted that the family and peers have an essential role to play in promoting a healthy lifestyle and well-being of learners. Leaners are free to talk to their peer rather than their parents due to cultural barriers

\section{Limitations}

This study has various limitations. Respondents may have felt uncomfortable about sharing their unique experiences of social distancing during COVID-19 and prevention strategies with the researchers. If that were the case, then the findings may be more factual for those learners who were more comfortable sharing their experiences than for those who might have been less comfortable doing so. Moreover, respondents have provided accounts of their most recent experiences about their experience in connection with social distance duringCOVID-19 and prevention strategies that may evolve. Future studies should interview family members, teachers and peers of the learners on COVID-19 or any crisis or natural disaster prevention support they perceive as assisting the youth.

\section{References}

Aliyyah, R. R., Rachmadtullah, R., Samsudin, A., Syaodih, E., Nurtanto, M., \& Tambunan, A. R. S. (2020). The Perceptions of Primary School Teachers of Online Learning during the COVID-19 Pandemic Period: A Case Study in Indonesia. Journal of Ethnic and Cultural Studies, 7(2), 90-109. DOI: http://dx.doi.org/10.29333/ejecs/388

Aydin, H. (2019). The effect of multiple intelligence (s) on academic success: A systematic review and meta-analysis. EURASIA Journal of Mathematics, Science and Technology Education, 15(12), em1777.

Bjorklund, A, \& Salvanes, K. (2011). Education and family background: Mechanisms and policies. In E. Hanushek, S. Machin, \& L Woessmann (Eds), Handbook of the economics of education, Vol. 3 (pp. 201-247). Elsevier B.V. https://econpapers.repec.org/bookchap/eeeeduchp/3-03.htm

Boutelier, S. (2019). Limiting Learning Environments through Domestication. Journal of Culture and Values in Education, 2(1), 45-55. https://doi.org/10.46303/jcve.02.01.4

Boz Yaman, B. (2019). A multiple case study: What happens in peer tutoring of calculus studies? International Journal of Education in Mathematics, Science and Technology 7(1), 53-72. doi:10.18404/ijemst.328336 ttps://files.eric.ed.gov/fulltext/EJ1204149.pdf

Campbell, L. (2020). How COVID-19 could affect kids' long-term social development. Healthline. https://www.healthline.com/health-news/social-distancing-effects-onsocial-development

Cancer Care. (2020). Managing the emotional impacts of social distancing. https://www.cancercare.org/publications/400managing_the_emotional_impacts_of_so cial_distancing

Cascio, C. (2014). What are some advantages and disadvantages of peer tutoring? Seattlepi. https://education.seattlepi.com/advantages-disadvantages-peer-tutoring-3515.html 
Galkiene, A., \& Puskoriene, G. (2020). Development of Adaptation Tools for Pupils on the Autism Spectrum in Microsystems. Research in Social Sciences and Technology, 5(2), 1-21. https://doi.org/10.46303/ressat.05.02.1

Garbe, A., Ogurlu, U., Logan, N., \& Cook, P. (2020). Parents' Experiences with Remote Education during COVID-19 School Closures. American Journal of Qualitative Research, 4(3), 45-65. https://doi.org/10.29333/ajqr/8471

Hau Yan Ho, A. (2020, May 12). COVID-19 and social distancing: Impacts on youths, university and post-secondary students. Academic SG. https://www.academia.sg/academic-views/covid-19-and-social-distancing-impacts-onyouths-university-and-post-secondary-students/

Ho, A.H.Y., Chui, C.H.K., \& Borschel, M. (2017). Understanding and managing youth and elderly suicide in developed East Asia: The imperative of compassion in public health. In G. Cox \& N. Thompson (Eds.), Handbook of traumatic loss: A guide to theory and practice (107-122). Routledge.

John-Steiner, V., \& Mahn, H. (1996). Sociocultural approaches to learning and development: A Vygotskian framework. Educational Psychologist, 31(3-4), 191-206. https:/doi.org/10.1080/00461520.1996.9653266

Kelley, D. (2020). The Person Within the Mask: Mask-Wearing, Identity, and Communication. American Journal of Qualitative Research, 4(3), 111130. https://doi.org/10.29333/ajqr/8712

King, N., \& Horrocks, C. (2010). Interviews in qualitative research. SAGE Publications.

Kumar, D. N. S. (2020, April 29). Impact of Covid-19 on higher education. Higher Education Digest. education/

Learmonth, A. E. (2018). An Encyclopedic overview of child development and directions for the future: Developmental Psychobiology 60(4), 491-492.

López, L., \& Rodó, X. (2020). The end of social confinement and COVID-19 re-emergence risk. Nature Human Behaviour, 4, 746-755. https://doi.org/10.1038/s41562-020-09088

Makola, O. \& Modise, M. A. (2018). Investigation of the voice of learners regarding HIV/AIDS in South African communities. Commonwealth Youth and Development, 1, 1-10. https://doi.org/10.25159/2663-6549/3514

McLeod, S. A. (2007). Lev Vygotsky. SimplyPsychology. http://www.simplypsychology.org/vygotsky.html

Modise, M.A. (2017). HIV/AIDS prevention support resourcing with family and peers: University student perspectives. Journal of Psychology in Africa Journal of Psychology Africa, 27(3) 290-293, http://dx.doi.org/10.1080/14330237.2017.1321864

Mohamedbhai, G. (2020, April 9). COVID-19: What consequences for higher education? World University News. Africa Edition. https://www.universityworldnews.com/post.php?story=20200407064850279

Molefe, M.(2018). Personhood and rights in an African tradition. South African Journal of Political Studies, 45(2), 217-231. https://doi.org/10.1080/02589346.2017.1339176

Monkeviciene, O., Vildziuniene, J., \& Valinciene, G. (2020). The Impact of Teacher-Initiated Activities on Identifying and Verbalizing Ways of Metacognitive Monitoring and Control in Six-Year-Old Children. Research in Social Sciences and Technology, 5(2), 72-92. https://doi.org/10.46303/ressat.05.02.5

Neubauer, B. E., Witkop, C.T., \& Varpio, L. (2019). How phenomenology can help us learn from the experiences of others. Perspectives on Medical Education, 8, 90-97. https://doi.org/10.1007/s40037-019-0509-2 
Ojha, A. (2020). Is Pandemic a Class-Ridden? An Appraisal from New York City. Journal of Ethnic and Cultural Studies, 7(3), 129-141. DOI: http://dx.doi.org/10.29333/ejecs/535

Polit. D.F., \& Beck, C.T. (2014). Focusing on the fundamentals. A simplistic differentiation between qualitative and quantitative research. Nephrology Nursing Journal, 45(2), 209213.https://insights.ovid.com/nephrology-nursing/nenuj/2018/03/000/focusingfundamentals- simplistic-differentiation/48/01217118

Serafini G, Parmigiani, B. Amerio, A., Aguglia, A., Sher, L, \& Amore, M. (2020) The psychological impact of COVID-19 on the mental health in the general population QJM: An International Journal of Medicine, 113(8), 529-535. doi: 10.1093/qjmed/hcaa201

Shabani, K. (2016). Applications of Vygotsky's sociocultural approach for teachers' $\begin{array}{lll}\text { professional } & \text { development, } & 3(1),\end{array}$ 177.http://dx.doi.org/10.1080/2331186X.2016.1252177

Sullivan, H.S. (1953). The interpersonal theory of psychiatry. W.W. Norton \& Company.

Tarman, B. (2020). Editorial: Reflecting in the shade of pandemic. Research in Social Sciences and Technology, 5(2), i-iv. https://doi.org/10.46303/ressat.05.02.ed

Tasman, A., Kay, J., Lieberman, J.A. First, M.B., \& Wiley, M.J. (2008). Psychiatry (3 ${ }^{\text {rd }}$ ed.). John Wiley \& Sons.

Topping, K. J. (2005). Trends in peer learning. Educational Psychology, 25(6), 631645.https://doi.org/10.1080/01443410500345172

Visser, S. (2015). Child development. www.developafrica.org.

Williams, D. (2020). Child Development Theories. https://www.firstdiscoverers.co.uk

World Health Organisation. (2020, January 21). Novel Coronavirus (2019-nCoV) Situation report-1.https://www.who.int/docs/default-source/coronaviruse/situationfreports/20200121-sitrep-1-2019-ncov.pdf?sfvrsn=20a99c10_4

\section{Notes on Contributors}

Ncube Sikhangezile serves as senior teacher at Nyamandlovu Secondary School in Matabeleland North Province in Zimbabwe. A part- time lecturer in the department of disability studies and special needs education at Zimbabwe Open University. She is an interdisciplinary sociologist, with a wealth of more than twenty-three years of professional experience from different workplaces. She holds a BED, Honours in Education, Masters in Education and currently doing Doctor of Education at Central University of Technology in Free State, South Africa. Her areas of research and activism include the social context of adult and continuing education with particular emphasis on gender issues, disability issues and religious issues.

Dr. Motalenyane Alfred Modise is senior lecturer at Central University of Technology (CUT) in Free State of South Africa. He was appointed as the Departmental Manager for Department of Education Professional Studies at CUT during 2019, at the same time serve in the following committees at CUT: Member of Senate, Title Registration Committee, Faculty research committeet, ransformation committee, HIV/AIDS Committee and Faculty board member, He has proven himself as a scholar by presenting papers in the national, international conferences, publishing papers in different Journals and also supervise masters and $\mathrm{PhD}$ students. He received funding for different project from different stakeholders. 